\title{
Ketone bodies in blood of dairy cows: Prevalence and monitoring of subclinical ketosis
}

\author{
Marek Krempaský, Iveta Maskal'ová, Lukáš Bujňák, Vladimír Vajda \\ University of Veterinary Medicine and Pharmacy in Košice, Department of Nutrition, \\ Dietetics and Animal Breeding, Košice, Slovak Republic \\ Received January 17, 2014 \\ Accepted May 28, 2014
}

\begin{abstract}
The aim of this study was to investigate the relationship between concentration of non-esterified fatty acid and ketone bodies in blood of dairy cows, and to evaluate these concentrations for the detection of prevalence of subclinical ketosis. The second aim was to compare the concentration of $\beta$-hydroxybutyric acid determined by an electronic handheld meter Precision Xtra ${ }^{\circledR}$ with serum concentration of $\beta$-hydroxybutyric acid analysed in laboratory with izotachometric and photometric method, respectively. Blood samples were collected from jugular vein 4-6 h after morning feeding in three groups of Holstein cows $(n=909)$ according to the lactation phase from 51 different herds with similar husbandry characteristics. High lipomobilization (non-esterified fatty acid $\geq 0.35 \mathrm{mmol} \cdot \mathrm{l}^{-1}$, mean concentration $0.34 \pm 0.15 \mathrm{mmol} \cdot \mathrm{l}^{-1}$ ) was detected in $30.3 \%$ of antepartum cows, while increased concentrations of $\beta$-hydroxybutyric acid $\left(\geq 1.0 \mathrm{mmol} \cdot \mathrm{l}^{-1}\right.$, prevalence of subclinical ketosis) were detected in $18.5 \%$ and $14.1 \%$ of the early lactation and mid lactation cows, respectively. The correlation coefficient $(\mathrm{r}=0.84, P<0.001 ; \mathrm{r}=0.93$, $P<0.001)$ was found between measurements of whole blood $\beta$-hydroxybutyric acid of 60 and 38 dairy cows determined with the Precision $\mathrm{Xtra}^{\circledR}$ test and plasma or serum $\beta$-hydroxybutyric acid concentration determined by isotachophoresis and photometrical method, respectively. Our results show that the monitoring of changes in the blood concentration of $\beta$-hydroxybutyric acid in high-yielding cows in the early postpartum period by the electronic handheld meter Precision $\mathrm{Xtra}{ }^{\circledR}$ may be effective in reducing the incidence of ketosis and health problems associated with ketosis in dairy cattle herds.
\end{abstract}

Peripartal period, non-esterified fatty acid, $\beta$-hydroxybutyric acid, laboratory and farm diagnostic test

The case definition of subclinical ketosis $(\mathrm{SCK})$ is characterized by serum $\beta$-hydroxybutyric acid (BHBA) concentrations $>1.0$ to $1.4 \mathrm{mmol} \cdot \mathrm{l}^{-1}$ in the absence of clinical signs of ketosis (Duffield et al. 1998; Iwersen et al. 2009; Rollin et al. 2010). It is well known that severe negative energy balance (NEB) in the periparturient period increases the risk of postpartum diseases such as retained placenta, milk fever, metritis, mastitis, clinical ketosis, and displaced abomasum (Dohoo et al. 1983; Duffield et al. 2009; Chapinal et al. 2011). Subclinical ketosis has a prevalence of around 7 to $43 \%$ (Geishauser et al. 1998; Enjalbert et al. 2001; Suthar et al. 2013). Because of the economic consequences, it is very important to diagnose SCK in dairy cows, especially during early lactation for earlier treatment and prevention of further losses. Ketones can be determined in the laboratory with enzyme photometric, chromatographic method or isotachophoresis but also with farmed cow-side tests which include semi-quantitative determination of ketone bodies in milk and urine, or direct electrochemical test for measurement of BHBA in blood (Iwersen et al. 2009).

The first aim of this study was to determine the prevalence of SCK in the postpartum period. The first group consisted of early postpartum cows until 21 days of lactation, and the second group included mid postpartum cows between 21 to 90 days of lactation (Experiment 1). The second aim of this study was to determine the diagnostic performance

Address for correspondence:

MVDr. Marek Krempaský

Department of Nutrition, Dietetics and Animal Breeding

University of Veterinary Medicine and Pharmacy in Košice

Komenského 73,041 81 Košice, Slovak Republic

Phone: +421902310778

E-mail: krempaskymarek@gmail.com

http://actavet.vfu.cz/ 
and to compare the BHBA concentration determined by an electronic handheld meter Precision $\mathrm{Xtra}^{\circledR}$ with serum concentration of $\beta$-hydroxybutyric acid analysed in the laboratory with isotachophoresis and photometric method, respectively (Experiment 2).

\section{Materials and Methods}

Experiment 1 was performed in Slovakia at 51 different dairy farms under similar husbandry and feeding conditions. Data were collected over a 4-year period (from January 2010 until November 2013). A total of 909 animals from farms approximately with 350 to 500 Holstein-Friesian cows, and with a mean annual milk production of 8,000 to $9,500 \mathrm{~kg}$ of milk during 305-day lactation, were selected for the experiment according to the lactation phase. The group before calving consisted of antepartum cows 21 days before calving $(n=302)$. After the partum, the first group consisted of early postpartum cows until 21 days of lactation $(\mathrm{n}=303)$, and the second group included mid postpartum cows between 21 to 90 days of lactation $(\mathrm{n}=304)$. The cows 21 days before calving were kept in a free-stall barn and fed a total mixed ration (TMR) formulated for dry cows, based on maize silage, grass haylage and straw supplemented with minerals in the dry period and with an increasing share of concentrates. Cows after calving were housed in a free-stall system and the animals were fed a TMR based on maize silage, alfalfa, and grass haylage. In the complete diet, the concentrate was supplemented with protein, minerals, vitamins and milk production enhancers (protein and rumen-protected fat). Cows after calving were fed a TMR formulated to meet or exceed NRC (2001) recommendations and to produce 35-40 $\mathrm{kg}$ of milk, 6.85-7.10 $\mathrm{MJ} \cdot \mathrm{kg}^{-1}$ net energy for lactation and $16-18 \%$ crude protein. Feed was offered twice daily using mixer wagons, and it was gathered up several times per day to ensure ad libitum access. Cows were milked twice daily around 04:00 $\mathrm{h}$ and 16:00 $\mathrm{h}$. Blood samples were collected from the jugular vein 4-6 h after morning feeding and immediately delivered to laboratory. The NEFA were determined by the method of Duncombe (1964). The BHBA levels were measured using isotachophoresis (AE 103) and to compare serum BHBA concentration obtained with electronic meter, Precision Xtra ${ }^{\circledR}$ BHBA hand-held meter was used. For this comparison (one part of Experiment 2) 60 samples of blood of dairy cows were used (3 farms, from March 2013 until May 2013). Concentration of BHBA was measured with Precision Xtra ${ }^{\mathbb{R}}$ electronic hand held meter after delivery of blood samples to laboratory and before obtaining serum.

In Experiment 2 blood was collected on one commercial farm to compare BHBA concentration determined by Precision Xtra ${ }^{\circledR}$ electronic hand held meter with serum BHBA concentrations determined by photometrical method. Blood tests were performed in laboratory using $\beta$-Hydroxybutyrate Assay Kits (BioVision, USA). Cows on farm (Holstein-Friesian breed) were high-yielding with a milk production over 11,500 $\mathrm{kg}$ of milk during 305-day lactation. Animals selected for this experiment consisted of early postpartum cows until 21 days of lactation. Blood samples of $10 \mathrm{ml}$ of blood were collected from the coccygeal vessels of each of 38 cows $2-3 \mathrm{~h}$ after morning feeding using a tube without anticoagulant for laboratory and for on farm testing of BHBA with Precision Xtra ${ }^{\circledR}$ meter. The BHBA testing on farm was completed according to Precision Xtra ${ }^{\circledR}$ meter instructions immediately after blood collection. A ketone strip was attached to the Precision Xtra ${ }^{\circledR}$ meter until the "add blood" symbol appeared on the meter display. For each cow tested, a drop of blood was applied to the ketone test strip chamber. The meter indicated when the chamber was full. After $10 \mathrm{~s}$, the BHBA concentration was displayed on the meter and the value recorded.

\section{Laboratory tests}

Williamson et al. (1962) developed the enzyme catalysis-photometric method to test serum BHBA. Based on this method, a test kit was manufactured. The test kit required the use of an ultraviolet spectrophotometer or biochemistry analyser and could be used to test serum BHBA concentrations in humans and animals. Isotachophoresis (ITP) is a suitable analytical method for the quantification of ketone bodies in blood serum (Dolník and Buček 1981). Isotachophoresis is a technique used in analytical chemistry for selective separation and quantification of ionic analytes. It is a form of electrophoresis: charged analytes are separated based on ionic mobility, a factor which tells how fast an ion migrates through an electric field. In conventional ITP separations, sample is introduced between a zone of "fast" leading electrolyte and a zone of "slow" terminating (or: trailing) electrolyte.

\section{Farm cow-side test}

The direct electrochemical hand-held BHBA meter (PrecisionXtra ${ }^{\circledR}$, Abbott Diabetes Care, Abingdon, UK) ketone monitoring system is a simple and direct electrochemical test. The ketone test strip contains the enzyme $\beta$-hydroxybutyrate dehydrogenase, which oxidizes BHBA to acetoacetate. This reduces nicotinamide adenine dinucleotide $\left(\mathrm{NAD}^{+}\right)$to NADH. NADH is then reoxidized to $\mathrm{NAD}^{+}$by an electron transfer mediator molecule. The electrical current generated by this conversion is measured by the electronic hand-held BHBA meter and is directly proportional to BHBA concentration.

\section{Statistical analysis}

The obtained results were processed by mathematical-statistical methods using the GraphPad Prism 4 statistical program. Parameters of regression lines, unpaired $t$-test and one-way ANOVA were used. Correlation coefficients 
were calculated between BHBA concentrations in serum measured in the laboratory and values displayed on the electrical hand-held meter test (Precision Xceed ${ }^{\circledR}$ ) for whole blood. Unpaired $t$-test was used for comparing analysed BHBA concentrations in serum measured in the laboratory and values displayed on the electrical handheld meter test $\left(\right.$ Precision Xceed $^{\circledR}$ ) for whole blood. One-way ANOVA was used for comparing analysed BHBA concentrations in the antepartum period, postpartum period and peak of lactation. Non-significant differences were defined at $P \geq 0.05$.

\section{Results}

Experiment 1: Prevalence of subclinical ketosis in postpartum

Table 1 presents the mean concentration of non-esterified fatty acids (NEFA) and BHBA

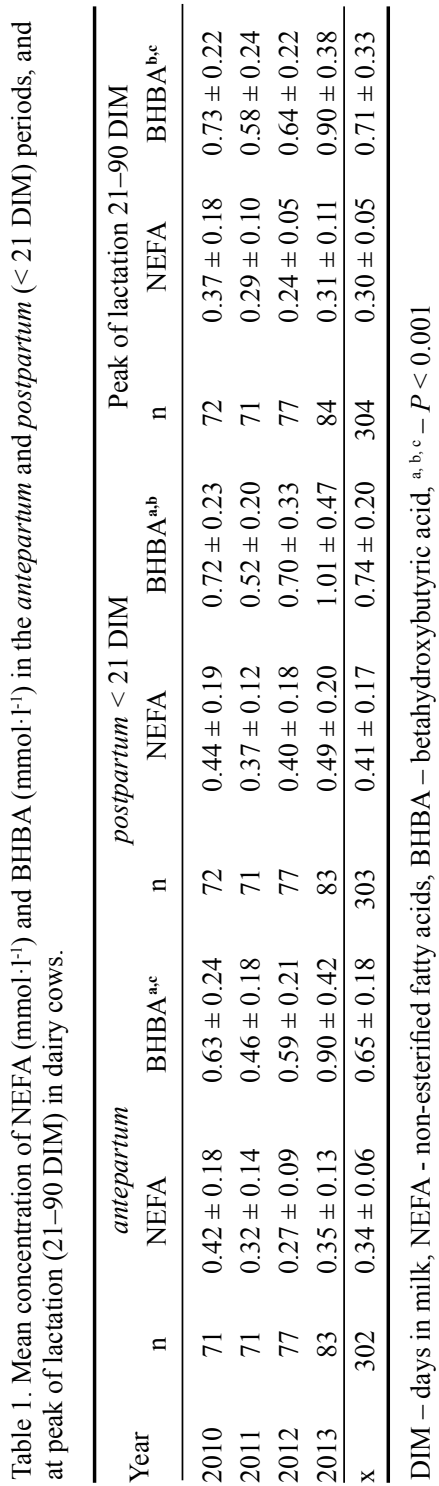

in the evaluated period (years 2010-2013) for all groups of cows used in the study of prevalence of subclinical ketosis. Cows in early lactation in the evaluated years had higher mean concentrations of BHBA $(0.74 \pm 0.34$ $\left.\mathrm{mmol} \cdot \mathrm{l}^{-1}\right)$ and NEFA $\left(0.41 \pm 0.17 \mathrm{mmol} \cdot \mathrm{l}^{-1}\right)$ compared to mid lactation cows (BHBA $0.71 \pm 0.33 \mathrm{mmol} \cdot \mathrm{l}^{-1}$ and NEFA $\left.0.30 \pm 0.15 \mathrm{mmol}^{-1} \mathrm{l}^{-1}\right)$. The threshold for NEFA is $0.35 \mathrm{mmol} \cdot \mathrm{l}^{-1}$ in the antepartum period, and $30.3 \%$ cows had elevated NEFA values in this close-up period. The threshold for NEFA is $0.7 \mathrm{mmol} \cdot \mathrm{l}^{-1}$ in the postpartum period, and $7.2 \%$ and $8.0 \%$ cows had elevated values of NEFA in early lactation ( $<21$ days in milk - DIM), and mid lactation (21-90 DIM), respectively. Overall prevalence of SCK during postpartum using a threshold of $\geq 1.0 \mathrm{mmol} \cdot \mathrm{l}^{-1}$ of blood BHBA was $18.5 \%$ and $14.1 \%$ in the early postpartum cows ( $<21$ days in milk, DIM) and mid lactation cows (21-90 DIM), respectively. The values of BHBA concentrations were significantly different in the antepartum period, postpartum period and peak of lactation $(P<0.001)$.

Experiment 2: Examination of diagnostic performance of the electronic hand-held BHBA meter (Precision Xtra ${ }^{\circledR}$ )

Correlation coefficient $\left(\mathrm{r}=0.84 ; \mathrm{R}^{2}=0.7067 ; P<0.001\right)$ was found between our measurements of whole blood BHBA of 60 dairy cows determined with the Precision $\mathrm{Xtra}^{\circledR}$ test and plasma BHBA concentration determined by isotachophoresis method. Correlation coefficient $\left(\mathrm{r}=0.95 ; \mathrm{R}^{2}=0.8838 ; P<0.001\right)$ was found between our measurements of whole blood BHBA of 38 dairy cows determined with the Precision Xtra ${ }^{\circledR}$ test and serum BHBA concentration determined by photometric method. Means, standard deviations, minimum and maximum values of BHBA concentrations determined using the two different methods are shown in Table 3. In comparison, values obtained by isotachophoresis vs. Precision $\mathrm{Xtra}^{\circledR}$ and photometry vs. Precision $\mathrm{Xtra}^{\circledR}$ were not significantly different $(P \geq 0.05)$. Measures of accuracy of analysed samples curried out by two laboratory and cowside methods are presented in Fig. 1. 
Table 2. Percentage of cows with elevated NEFA and BHBA in all groups of cows (A), and percentage of cows with balanced $\left(\leq 0.6 \mathrm{mmol} \cdot \mathrm{l}^{-1}\right)$, compensated $\left(0.61\right.$ to $\left.1.0 \mathrm{mmol} \cdot \mathrm{l}^{-1}\right)$ and uncompensated $\left(\geq 1.0 \mathrm{mmol} \cdot \mathrm{l}^{-1}\right)$ ketogenesis in dairy cows (B).

\begin{tabular}{lccc}
\hline A) & antepartum $\% \mathrm{n}=302$ & $<21$ DIM $\% \mathrm{n}=303$ & $21-90$ DIM $\% \mathrm{n}=304$ \\
\hline NEFA & 30.3 & 7.2 & 8.0 \\
BHBA & 10.6 & 18.5 & 14.1 \\
\hline B) BHBA mmol-1 ${ }^{-1}$ & $\leq 0.6$ & $0.61-1.0$ & $>1.0$ \\
\hline antepartum $\%$ & 59.3 & 30.1 & 10.6 \\
$<21$ DIM \% & 38.0 & 43.5 & 18.5 \\
$21-90$ DIM \% & 34.8 & 51.1 & 14.1 \\
\hline Mean \% & 44.1 & 41.5 & 14.4 \\
\hline
\end{tabular}

DIM - days in milk, NEFA - non-esterified fatty acids, BHBA - betahydroxybutyric acid

Table 3. Concentration of BHBA $\left(\mathrm{mmol} \cdot \mathrm{l}^{-1}\right)$ in dairy cows depending on the method of assessment.

\begin{tabular}{lcccc}
\hline Analytical method & Isotachophoresis & PrecisionXtra $^{\circledR}$ & Photometric $^{\circledR}$ & PrecisionXtra $^{\circledR}$ \\
\hline Number of cows & $\mathrm{n}=60$ & $\mathrm{n}=60$ & $\mathrm{n}=38$ & $\mathrm{n}=38$ \\
Mean \pm SD & $1.07 \pm 0.33$ & $0.95 \pm 0.37$ & $0.62 \pm 0.27$ & $0.75 \pm 0.39$ \\
Standard error & 0.0438 & 0.0492 & 0.0441 & 0.0640 \\
Interval & $0.70-2.40$ & $0.30-2.40$ & $0.30-1.30$ & $0.30-1.70$ \\
\hline
\end{tabular}

BHBA - betahydroxybutyric acid
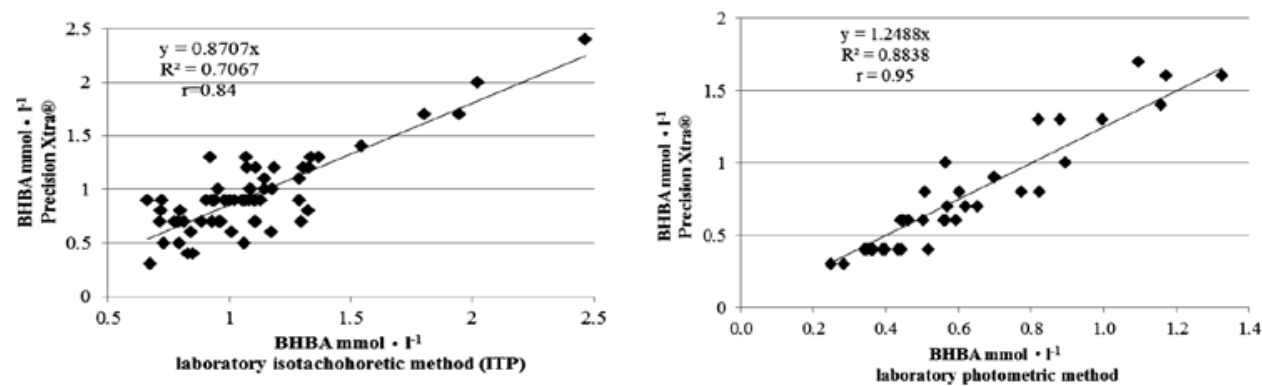

Fig. 1. Concentration of BHBA depending on the method of assessment (ITP vs. Precision Xtra $\left.{ }^{\circledR}, n=60\right)$ and (photometric method vs. Precision Xtra ${ }^{\circledR}, \mathrm{n}=38$ ).

BHBA - betahydroxybutyric acid

\section{Discussion}

Circulating concentrations of NEFA and BHBA measure aspects of success of adaptation to negative energy balance (Chapinal et al. 2011). NEFA concentration reflects the magnitude of fat mobilization from body reserves and reflects the energy and dry matter intake (Adewuyi et al. 2005), whereas BHBA reflects the completeness of oxidization of fat in the liver. 
Measurements of NEFA are most useful during the close-up period and in fresh cows. Values exceeding $0.7 \mathrm{mmol} \cdot \mathrm{l}^{-1}$ for more than 7 days after calving indicate severe negative energy balance or health problems, and suggest that transition and fresh cow management should be examined (Duffield et al. 2009).

In our study, elevated BHBA concentrations with a high risk of developing subclinical ketosis $\left(\geq 1.0 \mathrm{mmol}^{-1} \mathrm{l}^{-1}\right)$ were found in $18.5 \%$ and $14.1 \%$ of the early lactation dairy cows and mid lactation dairy cows, respectively. The first two weeks of lactation are the primary risk period for development of subclinical ketosis, defined by serum BHBA concentration of $1.2 \mathrm{mmol} \cdot \mathrm{l}^{-1}$ or higher (Oetzel 2013). A reasonable goal is to have less than 2 cows per 10 with BHBA above $1.2 \mathrm{mmol} \cdot \mathrm{l}^{-1}$ in the first 2 weeks after calving. Mc Art et al. (2011) reported an overall SCK incidence rate of $42.3 \%$ in 1,717 cows in four large commercial herds. Suthar et al. (2013) reported $21.8 \%$ overall prevalence of SCK in the postpartum period (i.e., blood BHBA $\left.\geq 1.2 \mathrm{mmol}^{-1} \mathrm{l}^{-1}\right)$ in 10 European countries $(5,884$ dairy cows), ranging from 11.2 to $36.6 \%$.

The gold standard diagnostic test for subclinical ketosis is determination of BHBA in serum or plasma (Duffield 2000). Serum BHBA determination is useful for monitoring feeding management practices by examination of individual cows and evaluating herd health. Quantitative determination of BHBA depends on special laboratory equipment and requires blood sampling, centrifugation, freezing of plasma or serum samples, and transport of frozen materials to the laboratory. Several rapid cow-side tests have been developed to alleviate these inconveniences, to reduce laboratory costs, and to provide results immediately after sampling (i.e., cow-side). Several cow-side diagnostic tests (dipsticks, powders, tablets) for ketosis are commercially available. These are designed to detect acetoacetate, and to a lesser degree acetone, in urine (e.g., Ketostix strip, Bayer, Leverkusen, Germany) or BHBA in milk (e.g., Ketolac, Biolab, München, Germany) based on the degree of colour change. The tests can be used semi-quantitatively because the colour change is more intense in the presence of higher concentrations of ketone bodies (Oetzel 2013). The upper threshold of BHBA concentration for SCK $\left(\geq 3.0 \mathrm{mmol} \cdot \mathrm{l}^{-1}\right)$ should be the onset of clinical signs (Oetzel 2013). The clinical signs of ketosis in early lactation dairy cows include decreased appetite, weight loss, decreased milk production. Ketosis is diagnosed whenever there are elevated concentrations of ketones in the blood, urine, or milk of a cow (a positive cow-side test result for ketosis) (Oetzel 2013). These clinical signs are mostly quite subjective in nature, and the cow-side tests for ketosis (to determine ketone in milk and urine under practical conditions) commonly used by dairy producers have considerable variability in their sensitivity and specificity for detecting ketosis (Chapinal et al. 2011). Using blood BHBA testing to determine the incidence or prevalence of SCK in a herd on the farm (electronic BHBA hand-held meter Precision $\mathrm{Xtra}^{\circledR}$ ) can be a powerful and useful clinical tool with high specificity and sensitivity for ketosis diagnosis (>98\%) (Oetzel 2013), especially in the case of subclinical ketosis, when cows above the threshold of BHBA $\left(1.2 \mathrm{mmol} \cdot \mathrm{l}^{-1}\right)$ probably should be detected as having clinical ketosis. The reported mean coefficient of determination $\mathrm{R}^{2}$ between handheld meter results and laboratory BHBA results is $0.86(\mathrm{r}=0.92)$ (Oetzel 2013).

Ketosis is a prevalent and important disease, which is associated with an increased risk of left displaced abomasum, decreased milk production, and decreased reproductive performance (Chapinal et al. 2011). Nogalski et al. (2012) show that monitoring changes in the body condition, and non-esterified fatty acids and $\beta$-hydroxybutyric acid blood concentrations in high-yielding cows in the transition period followed by taking relevant disease-control measures, may be effective in reducing the incidence of retained placenta and ketosis in dairy cattle herds. Prevalence determination of subclinical ketosis is useful for routine monitoring and investigation of the health and performance of transition cows. Early detection of SCK by cow-side blood test followed by adequate treatment 
and management reduces the negative impacts of SCK. Our results show that monitoring changes in $\beta$-hydroxybutyric acid blood concentration in high-yielding cows in the early postpartum period by electronic hand-held Precision Xtra ${ }^{\circledR}$ meter may be effective in reducing the incidence of ketosis and ketosis-related health problems in dairy cattle herds.

\section{Acknowledgement}

The study was supported by the grant VEGA 1/0970/11 and KEGA 016UVLF-4/2012.

\section{References}

Adewuyi A, Gruys E, Van Eerdenburg F 2005: Non esterified fatty acids (NEFA) in dairy cattle. A review. Vet Q 27: $117-126$

Chapinal N, Carson M, Duffield T, Capel M, Godden S, Overton M, Santos J, Le Blanc S 2011: The association of serum metabolites with clinical disease during the transition period. J Dairy Sci 94: 4897-4903

Dohoo I, Wayne Martin SW, Meek A, Sandals W 1983: Disease, production and culling in Holstein-Friesian cows I. Prev Vet Med 1: 321-334

Dolník V, Boček P 1981: Determination of pyruvate, lactate, acetoacetate, and 3-hydroxybutyrate in serum by capillary isotachophoresis. J Chrom 225: 455-458

Duffield T, Sandals F, Leslie K, Lissemore K, McBride B, Lumsden J, Dick P, Bagg R 1998: Efficacy of monensin for the prevention of subclinical ketosis in lactating dairy cows. J Dairy Sci 81: 2866-2873

Duffield T 2000: Subclinical ketosis in lactating dairy cattle. Vet Clin North Am Food Anim Pract 16: 231-253

Duffield T, Lissemore K, McBride B, Leslie K 2009: Impact of hyperketonemia in early lactation dairy cows on health and production. J Dairy Sci 92: 571-580

Duncombe 1964: The colorimetric microdetermination of non-esterified fatty acids in plasma. Clin Chim Acta 9: $122-125$

Enjalbert F, Nicot MC, Bayourthe C, Moncoulon R 2001: Ketone bodies in milk and blood of dairy cows: relationship between concentrations and utilization for detection of subclinical ketosis. J Dairy Sci 84: 583-589

Geishauser T, Leslie K, Kelton D, Duffield T 1998: Evaluation of five cowside tests for use with milk to detect subclinical ketosis in dairy cows. J Dairy Sci 81: 438-443

Iwersen M, Falkenberg U, Voigtsberger R, Forderung D, Heuwieser W 2009: Evaluation of an electronic cowside test to detect subclinical ketosis in dairy cows. J Dairy Sci 92: 2618-2624

McArt J, Nydam D, Ospina P, Oetzel G 2011: A field trial on the effect of propylene glycol on milk yield and resolution of ketosis in fresh cows diagnosed with subclinical ketosis. J Dairy Sci 94: 6011-6020

National Research Council 2001. Nutrient Requirements of Dairy Cattle, $7^{\text {th }}$ rev. ed. Washington, D.C., National Academy Press

Nogalski Z, Wroński M, Lewandowska B, Pogorzelska P 2012: Changes in the blood indicators and body condition of high yielding Holstein cows with retained placenta and ketosis. Acta Vet Brno 81: 359-364

Oetzel G 2013: Understanding the impact of subclinical ketosis. 24 ${ }^{\text {th }}$ Ruminant Nutrition Symposium. Available at: http://dairy.ifas.ufl.edu/rns/2013/2_oetzel.pdf. Last modified February 2013. Accessed February, 2013

Rollin E, Berghaus R, Rapnicki P, Godden S, Overton M 2010: The effect of injectable butaphosphan and cyanocobalamin on postpartum serum $\beta$-hydroxybutyrate, calcium, and phosphorus concentrations in dairy cattle. $\mathrm{J}$ Dairy Sci 93: 978-987

Suthar VS, Canelas-Raposo J, Deniz A, Heuwieser W 2013: Prevalence of subclinical ketosis and relationships with postpartum diseases in European dairy cows. J Dairy Sci 96: 2925-2938

Williamson H, Mellanby J, Krebs H 1962: Enzymic determination of D(-)- $\beta$-hydroxybutyric acid and acetoacetic acid in blood. J Biochem 82: 90-96 